\title{
油脂含有食品の酸化変性に関する研究
}

\section{Studies of Oxidizing Denaturation of Fat Contained in the Food}

\author{
即席ラーメンの光線と温度による影響について \\ Effects of Light and Temperature on the "Instant Lamen"
}

(昭 和 44 年 7 月 24 日 受 理)

\section{日下兵 唡* 深 沢輝* 松尾 登* (Hyozi Kusaka) (Akira Fukazawa) (Noboru Matsuo)}

Preservation of commercial "instant lamen" has been studied from a practical point of view with special regard to oxidizing denaturation.

"Instant lamen" was wrapped with color cellophane (red or green) as filter and then was exposed to sunlight and fluorescent lamp.

The peroxide value of fat that was extracted with ether from the sample was measured at regular time intervals.

Consideration of the transmittance of the color cellophane in ultraviolet and visible regions and of the relative energy of sunlight and the fluorescent lamp showed that $450 \sim 550 \mathrm{~m} \mu$ and ultraviolet region near $385 \mathrm{~m} \mu$ had considerable influence on the denaturation of the lamen.

The denaturation of the lamen was also carried out about the influence of various temperatures (room temp., 30,40 and $50^{\circ} \mathrm{C}$ ) under sealed condition in a paste-board box-that is, in the same condition as in that of transportation and storage.

As the result, in the case of the room temperature and $30^{\circ} \mathrm{C}$, the fat extracted did not show any great change of the peroxide value. Under conditions of 40 and $50^{\circ} \mathrm{C}$, however, the peroxide value gradually increased.

As above mentioned, it has been found out that no matter how high the surrounding temperature may be, for instance, during the summer season, if the light of $450 \sim 550 \mathrm{~m} \mu$ of visible portion and ultraviolet region near $385 \mathrm{~m} \mu$ are eliminated the preservation of the "instant lamen" under vacuum, is possible without oxidizing denaturation over a period of a month.

\section{緒言}

近年大衆食品として普及している即席ラーメンの品質 に関して種々の問題が扰きている。即席ラーメンは大部 分が油揚げ処理されていることから品質面での問題は脂 質の変性にもとつく製品の劣化がそのほとんどであると 考えられる。

市販即席ラーメンの脂質の酸化程度を調査した山下'1) の報告によると，ラーメン中の脂質含量は14〜26\%の範 囲にあり，これらの過酸化物価は大部分か $10 \mathrm{me} / \mathrm{kg}$ 以 下であったが, あきらかに不良品と判断しうるものは過 酸化物価, 酸化とも非常に高く, 過酸化物価の最高値を 示したものは $504 \mathrm{me} / \mathrm{kg}$ の市販品すあったと報告されて いる。

* 成蹊大学工学部
これらの変性の原因が油揚げ時の揚油にある場合と， 㱔品となった以後の保存条件や日数の経過により含有脂 質の変敗に上る慗品の劣化とが考えられる。保存条件や 経過日数を考虑した場合, 㱔品を劣化させる素因は本質 的に含有脂質の自動酸化にあるので，包装状態および保 存する環境として温度, 湿度, 光線によっでらける影響 が大である。

同じく山下¹ は同一サンプルの長期間にわたる経時的 観察により, 即席ラーメンの保存試験を行ない, 室温開 封状態で45日経過の時点で過酸化物価 $296.7 \mathrm{me} / \mathrm{kg}$, 酸 価17.5の最高値に達したことを示しており，さらに光線 による影響では紫外部よりも可視部の光線の影響を重視 し，紫外線防止加工を施したフィルムにより包装された すのでる白色䝁光燈下に拈ける脂質の酸化防止効果は注 とんどなく，濃い赤色フィルムでは明らかに効果があっ 
たと述べている。

渡迅 ${ }^{2)}$ はフィルム包装に括ける光線の影䇾に関して, 大豆油をスポンジに吸収させ， 7 種類のフィルムで含気 密封したすのについて光線による变性を調べた結果, $385 \mathrm{~m} \mu$ の紫外線はいずれのフィルムに打いてす直射日 光よりる過酸化物価にして約 3 倍の変性を与えることを 示し, $250 \mathrm{~m} \mu$ の紫外線でははとんど影響はなかったと 報告している。また同報告によると，真空包装の場合は 柴外線の透過率を考えるよりる，包装フィルムの酸素透 過率の方がより考虑されるべきであり，共存酸素量が高 い場合は紫外線の透過性が問題となると言及している。

これらのごとく食品中に含有する脂質の変性に関する 研究は数多くなされているが, 著者らはより実際的な場 合を想定して，市販即席揚げめんの保存条件を検討する ため, 色セロハンのフィルター効果を自然光線下と白色 螢光登光線下による影繁と, さらに温度による変性を, 主に過酸化物価をその示標として経時的に测定した結果 について報告する。

\section{実験}

1. 光による影製とフィルター効果

（1）実験に供した試料はM社製の即席ラーメンであっ て, 同一弊造過程のもので製造直後のものを直接工場よ り購入して使用した。これはスープ部分は粉末として別 添されているので実験の対象より除外した。サンプルは すへて販売時と同様に包装されたままの状態で種々の保 存実験を行なった。原試料よりエーテル抽出した油脂を ケン化, 酸分解, エチルエステルとしたすのについて GLC 分析を行なった結果の脂肪酸組成を表 1 に示す。

表 1 ラーメン抽出油の脂肪酸組成

\begin{tabular}{c|c|c|c|c|c|c}
\hline 含有量 & $\mathrm{C}_{14: 0}$ & $\mathrm{C}_{16: 0}$ & $\mathrm{C}_{16: 1}$ & $\mathrm{C}_{18: 0}$ & $\mathrm{C}_{18: 1}$ & $\mathrm{C}_{18: 2}$ \\
\hline$\%$ & 3.7 & 29 & 8.5 & 4.5 & 45.1 & 9.3 \\
\hline
\end{tabular}

（2）太陽光線下におけるフィルタ一効果

試料即席ラーメンを二階南面の風雨を避け得る場所に 日光が均等に照射されるよ5に配列し，これらの半分に

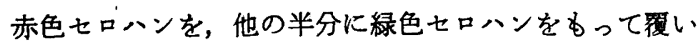
曝光した。実験期間は 7 月から9月にかけて行なった。

(3) 螢光登光線下におけるフィルタ一効果

図 1 に示した螢光登照射装置を 2 台自作し，その5ち 1 台に試料を底に一列に配し，その上を赤色七ロハンで 完全に覆った。2台の螢光登照射装置は同時に点隇出来 るようにして 1 日平均 8 時間の照射を行なった。

これらの実験にフィルターとして用いた赤色セロハン
図 1 螢光灯照射装置

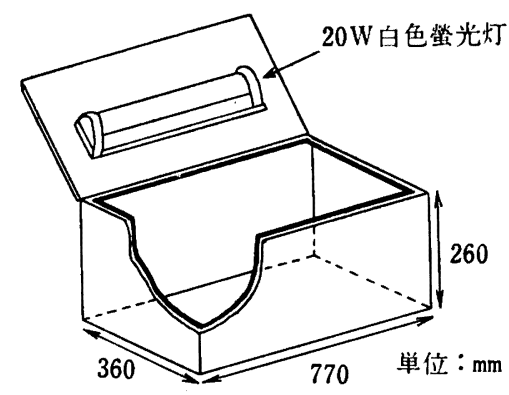

㘠 2 色セロハンの可視部スペクトル

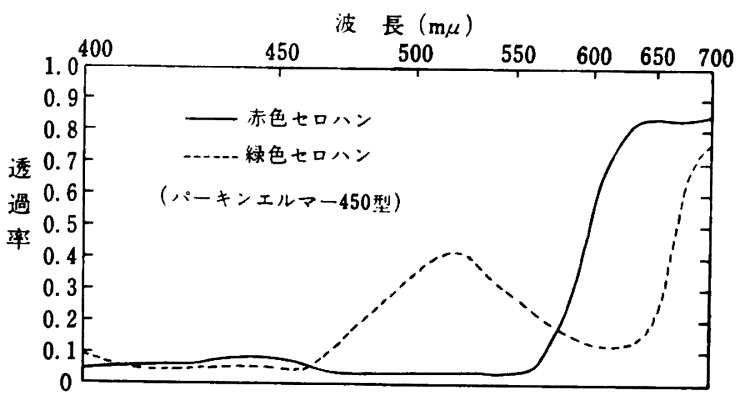

図3色七ロハンの紫外部スペクトル

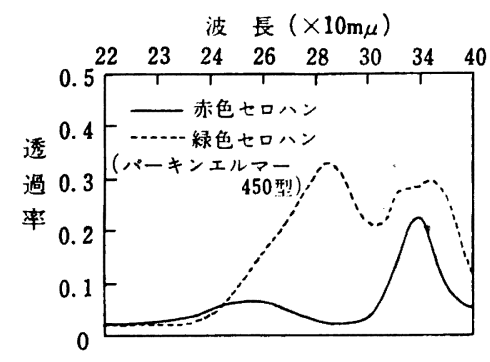

および緑色セロハンの可視部怙よび紫外部の吸収スペク トルを図 2 ，図 3 に示した。

2. 加熱变性実臨

（1）試料は $\mathrm{M}$ 社製即席ラーメンの市販されているもの を睡入して実験に供した。これは製造後すで 2 カ月を 経過したもので睡入時の POV および AV はそれぞれ 11.8，0.7であった。

(2) 加熱条件

上記即席ラーメンを出荷時と同状態の段ボールヶース に入れたまま各温度の恒温器に格納し, 测定のためケー スを開封した場合はテープで前と同状態に密封した。温 度条件は, 室温放置, $30^{\circ} \mathrm{C}, 40^{\circ} \mathrm{C}$ 扎よび $50^{\circ} \mathrm{C}$ の温度 とし, 室温以外は各温度とも各々の電気恒温器中に放置 した。 


\section{栄養と食 粗}

\section{3. 測定方法}

過酸化物価と酸価を測定するために試料即席ラーメン の1袋の全量をフードチョッパーによって微細な粉末と し，よく混合した後その20〜30 g を円筒沪紙に科り採り $100 \mathrm{ml}$ のエーテルを使用し,ソックスレー抽出器を用 いて $55^{\circ} \mathrm{C}, 4$ 時間の抽出を行ない, 後エーテルを普通蒸 留により留去し，さらに真空下に痕跡のエーテルを除去 して抽出油脂を得た。

過酸化物価および酸価の測定は「油脂化学便覧」の試 験法によった。

\section{結果および考察}

日光下に批いての赤色セロハンと緑色セロハンをフィ ルターとして用いた場合の効果を図 4 に示した。赤色セ

図4 日光下フィルター効果

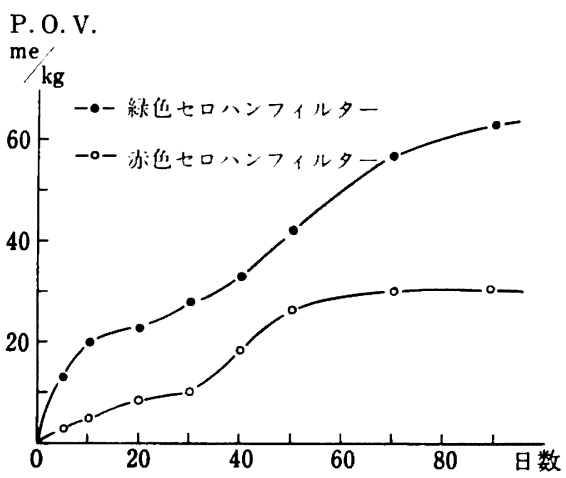

ロハンで覆ったものは45日経過て POV : $25 \mathrm{me} / \mathrm{kg}$ まで 徐々に上昇し，それ以後は平坦となり80日経過後におい ても POV : $30 \mathrm{me} / \mathrm{kg}$ を越えなかった。これに対し緑色 フィルターを用いた場合は 45 日経過で約 $35 \mathrm{me} / \mathrm{kg}, 80$ 日 経過で $60 \mathrm{me} / \mathrm{kg}$ に達し, なおる上䄯を続けている。赤色 セロハンの酸化抑制が緑色のそれよりる顕著であること

因 5 螢光燈下フィルター効果

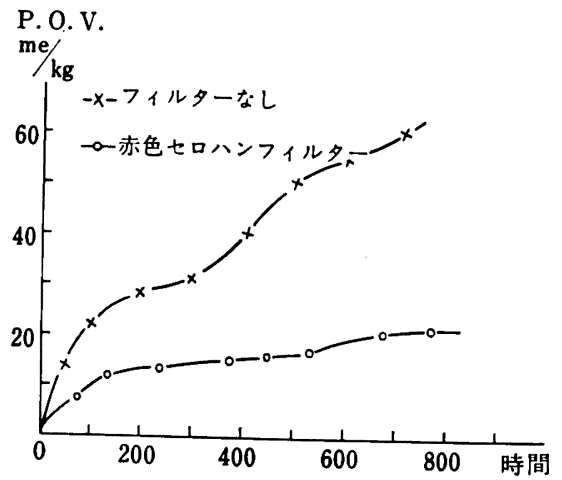

(584)
を認めた。

次に螢光登下における影整についてみてす図 5 に示し たように赤色セロハンで覆った即席ラーメンはヌントロ ールのセロハンで覆わなかった場合と比较して，かなり POV の上䄯は抑制されている。

コントロールは700時間の螢光登照射で約 $55 \mathrm{me} / \mathrm{kg}$ を 示しなおす上䄯を続けている。一方赤色セロハソを用い た場合はスタート時の POV : $0.9 \mathrm{me} / \mathrm{kg}$ のすのが, 100 時間の照射で $10 \mathrm{me} / \mathrm{kg}$ に上年し, 以後過酸化物の生成 は抑制され，700時間の経過において す約 $15 \mathrm{me} / \mathrm{kg}$ と POV は高い值を示さず， 日光下の影婎と同様に赤色セ ロハンの酸化防止効果を明らかにした。

日光下および螢光登下とも POV の湘定と併せて酸価 の測定を行なった。日光下の場合の酸価（以後 $\mathrm{AV}$ と 略す）の变化を表 2 に示したが，実験開始時のAV:0.1 の試料は赤色セロハンの場合 6 日目で 0.9 , 12日目て 1.5 と上畀し，その後降下ぎみとなったが，嚗光期間全体を 通しての大きな変化は見られず，緑色セロハンの場合す 6 日目で 1.6 と赤色セロハンの場合よりる上年している が以後は下降している。しかしいずれの場合す AV は 著しい変化を示さず，これは螢光燈下の照射においても 同様であった。

表 2 日光下フィルター効果実験における酸価の 变化

\begin{tabular}{cc|c|c|c|c|c|c|c|c}
\hline セロヘン & 数 & 0 & 6 & 12 & 23 & 33 & 44 & 65 & 86 \\
\hline 赤 & & 0.09 & 0.86 & 1.51 & 1.50 & 1.51 & 1.03 & 1.03 & 1.08 \\
\hline 緑 & & 0.09 & 1.59 & 1.32 & 1.20 & 1.11 & 1.07 & - & 1.04 \\
\hline
\end{tabular}

以上のごとく自然光線または溃光登光線下において赤 色七ロハンは緑色のそれよりす即席ラーメン中の脂質の 酸化を抑制することが明らかであるが，図2，図3に示 したように各々のセロハンの可視部および紫外部の領域 における透過度の差異をみると, 緑色セロハンは $515 \mathrm{~m} \mu$ に透過光を有するが，その波長領域において赤色セロ八 ンはほとんと透過光をすたない。また紫外部において緑 色セロハンは $260 \mathrm{~m} \mu$ 付近より $400 \mathrm{~m} \mu$ にわたって比較的 強く透過光をすち，赤色セロハンにおいては緑色のそれ よりす強くはないが300～400m $\mu$ にかけて透過光を有 し, 緑色セロハンにおいて紫外部の最大透過領域となっ ている $284 \mathrm{~m} \mu$ 付近では非常に弱くなっている。

これらのことより赤色セロハンは紫外部の $284 \mathrm{~m} \mu$ 付 近，可視部においては450〜 550m $\mu$ に透過光をるたない 故に緑色のセロハンょりる油脂の酸化を影著に抑制する 
すのと考えられるが， 渡辺 ${ }^{8)}$ の $250 \mathrm{~m} \mu$ の紫外線は油脂 の変性に全く関与世ず $385 \mathrm{~m} \mu$ の光線が 酸素共存の場合 重大な影響を及隹すという事実を考虑すれば， $284 \mathrm{~m} \mu$ の透過光は油脂の酸化にそれはどの影響を与えないと考 光, 結局 $385 \mathrm{~m} \mu$ 付近の紫外部と $450 \sim 550 \mathrm{~m} \mu$ の可視部 の光線が油脂の酸化变性を促進するすと思われる。

さらにこれらの光線による酸化変質の影響を自然光線 と螢光嬁光線の可視部に括ける相対エネルギー論的な面 より考察すれば図 6, 因7に示した通り自然光の分光エ ネルギー分布はその時の天候にもよるが青空よりの反射 光線が強い場合は短波長側の相対エネルギーが強く, 長 波長側が次第に弱くなっている。また太陽よりの直射光 の場合は $500 \mathrm{~m} \mu$ 付近の相対エネルギーは $400 \mathrm{~m} \mu$ のそれ よりす 2 倍以上の强度をすっている。白色螢光登の分光 エネルギー分布では $430 \mathrm{~m} \mu, 550 \mathrm{~m} \mu$ および $580 \mathrm{~m} \mu$ 付近 の波長領域の相対エネルギーが比較的強い。光の各波長 領域における相対エネルギーの強度が油脂の酸化に関係 するならば，可視領域における相対エネルギーの比較的 強い $580 \mathrm{~m} \mu$ 以下の領域を吸収する 赤色セロハンの効果 は明瞭である。また螢光燈の光線も赤色部より短波長側 に相対エネルギーの強い領域があるので同様に考兄られ る。

加熱变性実験における即席ラーメンの温度変化による

図 6 白色螢光登のスペクトルエネルギー分布 ${ }^{3)}$

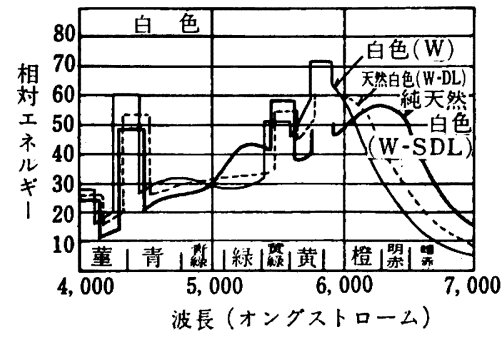

困7 自然光の分光エネルギー分布

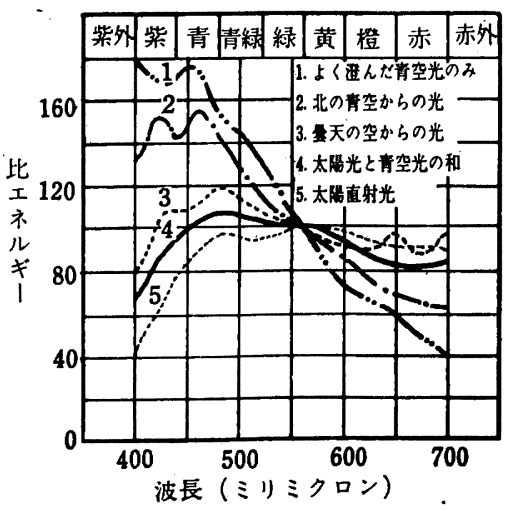

保存試験の結果を因 8 に示した。 $50^{\circ} \mathrm{C} ， 40^{\circ} \mathrm{C}$ の条件で は $30^{\circ} \mathrm{C}$, および室温の場合と比較して過酸化物価の上年 は大きい。室温では実験開始時の POV : $11.8 \mathrm{me} / \mathrm{kg}$ に 対し60日経過してもはとんど变化なく，30 ${ }^{\circ} \mathrm{C}$ の場合は 室温保存とさしたる差はないが，60日経過頃よりやや上 升の傾向にある。

本実験は即席ラーメンを真空包装した状態で，しかる 出荷時と同様に段ボール箱に密封し保存試験を行なった ものであって, 山下 ${ }^{1)}$ が即席ラーメンを室温, 明所, し かも包装袋より取り出した状態で保存試験を行なった結 果, 最初 POV : 0.8me/kg のすのか30日経過で172.6, 60 日経過で $149.6 \mathrm{me} / \mathrm{kg}$ であったとの報告は本実験の $50^{\circ} \mathrm{C}$ 恒温下で行なった場合と比較してるはるかに POV

因 8 即席ラーメンの温度変化による影響

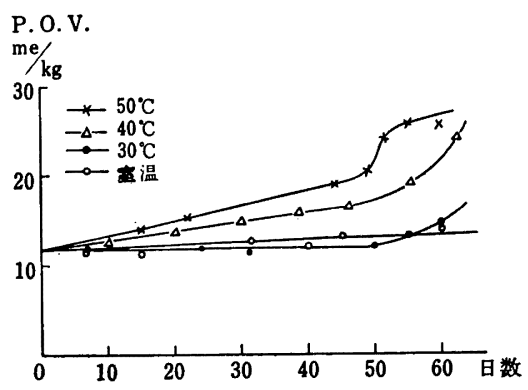

の上昇が大きい。すなわら開封状態のため酸素の吸収量 と, 明所に保存したことによる光線の影響が変性に大き く関与していると言える。光の影響については前述した が, 包装用フィルムについて渡边 ${ }^{2)}$ はポリセロフィルム の酸素透過案は $20 \mathrm{cc} / \mathrm{m}^{2}$, day atmであるが,ポリエチレ ソやポリプロピレン等の場合は $1700 \sim 4000 \mathrm{cc} / \mathrm{m}^{2}$, day atm と報告している。このことよりすポリセロフィルム に真空包装され，しかす段ボール中に密封されて保存さ れた場合は，その变性は著しく抑制されるるのと思われ る。

\section{要 約}

以上の結果扰よび考察を要約すると，日光下および螢 光登光線下に扣いて赤色セロハンをそのフィルターとし て用いた場合，緑色のセロハンよりるはるかに過酸化物 の生成を抑制する。このことはセロハンの可視部および 紫外部の吸収曲線と自然光および䖢光灯光線の相対エネ ルギーとより論ずれば $385 \mathrm{~m} \mu$ 付近の紫外部と, 可視部 においては450〜 550m $\mu$ の領域の光が油脂の酸化に及は す影響が大きい。

またこれらのことと加熱変性実験の結果を考虑すれば 油脂を含有する食品は, それが酸素透過率の低いポリセ 


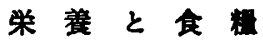

ロフィルムにより真空包装されて，しかも暗所に保存さ れるならば夏季のよらな時期です数カ月の保存は可能で あるが, 明所における保存, 陳列は $550 \mathrm{~m} \mu$ より短波長 の光線を除去することが必要である。 （本論文の要旨は昭和 42 年 5 月第21回日本栄養・食糧学 会総会（西宮）において発表した）

\section{文献}

1) 山下太郎：油化学, 14, 754 (1965)

2）渡辺 涉, 小林 胃, 久米寿昭, 川北 絃: 日水 会誌, 32, 327 (1966)

3）照明学会禍：照明のデーターブック改訂增補版 p. 118 (1962)（オーム社)

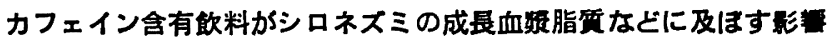

コーンスターチを基本とし乾燥コーヒーなどを補足し た飼料を体重 $120 \mathrm{~g}$ の雄シロネズミに54日間与兄，体 重, 肝臓, 腎蔵, 脾臓, 心蔵, 甲状腺の重量を計るとと すに，血中のコレステロール，リン脂質，拉よびトリ グリセリドを測定した。補足した試料は, 飼料 $100 \mathrm{~g}$ 当 り乾燥コーヒー $2.3 \mathrm{~g}$, 凍結乾燥茶 $1 \mathrm{~g}$, あるいは純粋 カフェイン140mg である。この添加量は, 体重70kg の 人が 1 日に12杯のこれらの飲料を飲んだばあいに相当す る。なおでんぷんを蔗瞊に置きかえた飼料についても同 様の試験を行なった。その結果, これらカフェイン飲料 物の添加は, 成長孪中荗器重量には影響を及はさはなっ たが，血漿脂質は飼料中のカフェイン量に比例して変化 した。すなわち，カフェインの掫取量が增すにつれて血
怔中のコレステロールとリン脂質は增え，トリダリセリ ドは滅少した。しかし，でんぷんを蔗㳓に圈きかえた飼 料ではカフェインの摂取量が增すにつれてトリダリセり ドが增し、コレステロールやリン脂質は变りなかった。 このような相違は，肝臟における脂質合成の敕合の異な ることに起因するすのである。脂質合成の指標として用 いられるパイルペイトキナーゼの活性は，でんぷん食で はコーヒーを添加しても変らなかったが，でんぷんを蔗 糖に置きかえると倍加した。

Influence of Caffeine-containing Beverages on the Growth, Food Utilization and Plasma Lipids of the Rat. by Naismith, D.J., et al.: J. Nutr., 97, (3), 375 381 (1969) 